\title{
SUSTENABLE ENERGY SOURCES UTILISATION
}

\author{
Kralikova, R. \& WeSSELY, E.
}

Abstract: Sufficient, renewable, safe and environmentally acceptable assurance of fuels and energy may be classified as one of most global tasks of mankind to which the countries worldwide pay extraordinary attention. Necessity of energy and exploitation of the energetic sources is increased permanently and it subjects to the population increase with which the economic and environmental problems are also advanced.

Key words: Environment, energetic plants, energy sources
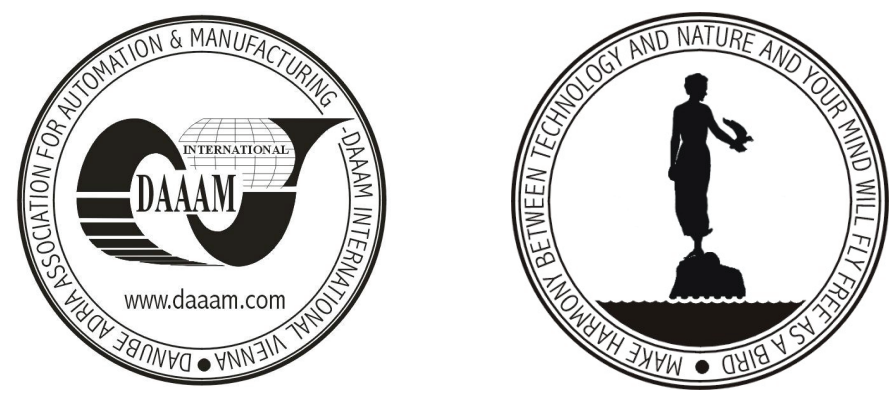

Authors' data: doc. Ing. PhD. Kralikova R.[uzena], doc. Ing. PhD. Wessely E.[mil], Technical University - Kosice, Faculty of Mechanical Engineering, Department of Environmental Studies, Park Komenskeho 5, 04187 Kosice, Slovak Republic, Ruzena.Kralikova@tuke.sk

This Publication has to be referred as: Kralikova, R. \& Wessely, E. (2006). Sustenable Energy Sources Utilisation, Chapter 30 in DAAAM International Scientific Book 2006, B. Katalinic (Ed.), Published by DAAAM International, ISBN 3-901509-47-X, ISSN 1726-9687, Vienna, Austria

DOI: $10.2507 /$ daaam.scibook.2006.30 